\title{
FLT3 Positive
}

National Cancer Institute

\section{Source}

National Cancer Institute. FLT3 Positive. NCI Thesaurus. Code C146671.

An indication that FLT3 expression has been detected in a sample. 